\title{
Akurasi Gambaran CT Scan Tulang Temporal Preoperatif dalam Menilai Kolesteatoma pada Penderita Otitis Media Supuratif Kronis (OMSK)
}

\author{
A. Fitrah Muhibbah, ${ }^{1}$ Mirna Muis, ${ }^{2}$ Nurlaily Idris, ${ }^{2}$ Andi A. Zainuddin, ${ }^{3}$ Masyita \\ Gaffar, ${ }^{4}$ Muhammad Ilyas ${ }^{2}$
}

${ }^{1}$ PPDS Ilmu Radiologi Fakultas Kedokteran Universitas Hasanuddin Makassar, Indonesia

${ }^{2}$ Departemen Radiologi Fakultas Kedokteran Universitas Hasanuddin Makassar, Indonesia

${ }^{3}$ Departemen IKM/IKK Fakultas Kedokteran Universitas Hasanuddin Makassar, Indonesia

${ }^{4}$ Departeman THT-KL Fakultas Kedokteran Universitas Hasanuddin Makassar, Indonesia

Email: fmuhibbah@gmail.com

\begin{abstract}
This study was aimed to determine the accuracy of preoperative temporal bone CTscan ini assessing cholesteatoma in chronic suppurative otitis media (CSOM) patients. This was a diagnostic test study conducted by comparing the findings of the preoperative temporal bone CTscan with the intraoperative findings of 54 CSOM patients who had a temporal bone CT-scan followed by surgery at the Hasanuddin University Hospital and the Jaury Academic Hospital. Assessment of cholesteatoma on a preoperative temporal bone CT-scan was performed when soft tissue density was found in the middle ear accompanied by bone erosion. In addition, an assessment was also carried out for the presence of ossicular, scutum, tympanic tegmen, facial nerve canal and mastoid tegmen erosions. The results indicated that the accuracy of preoperative temporal bone CT-scan in assessing cholesteatoma in CSOM patients was $87.04 \%$ with a sensitivity of $85 \%$, specificity of $88.23 \%$, a positive predictive value of $80.95 \%$, and a negative predictive value of $90.91 \%$. The sensitivity of the preoperative temporal bone CT-scan in assessing the highest erosion of cholesteatoma in the erosion of the scutum and tympanic tegmen (100\%) with the specificity and accuracy of the preoperative temporal bone CT scan of the in assessing erosions in cholesteatoma highest on mastoid tegman erosion (100\% and 96.29\%). In conclusion, preoperative CT scan of temporal bone has high accuracy, sensitivity, and specifity values in assessing cholesteatoma and erosions of surrounding structures.
\end{abstract}

Keywords: cholesteatoma, chronic suppurative otitis media (CSOM), temporal bone CT-Scan

\begin{abstract}
Abstrak: Penelitian ini bertujuan untuk mengetahui akurasi gambaran CT-scan tulang temporal preoperatif dalam menilai kolesteatoma pada penderita otitis media supuratif kronis (OMSK). Jenis penelitian ialah uji diagnostik yang membandingkan temuan pada CT scan tulang temporal preoperatif dengan hasil temuan intraoperatif pada 54 penderita OMSK yang menjalani pemeriksaan CT scan tulang temporal dilanjutkan dengan tindakan operasi di Rumah Sakit Universitas Hasanuddin dan Rumah Sakit Akademis Jaury. Penilaian kolesteatoma pada CT Scan tulang temporal preoperatif ketika ditemukan densitas jaringan lunak di telinga tengah yang disertai dengan erosi tulang. Selain itu, dilakukan penilaian adanya erosi osikula, skutum, tegmen timpani, kanalis nervus fasialis, dan tegmen mastoid. Hasil penelitian mendapatkan akurasi CT scan tulang temporal preoperatif dalam menilai kolesteatoma pada penderita OMSK sebesar $87,04 \%$ dengan sensitivitas $85 \%$, spesifisitas $88,23 \%$, nilai prediksi positif $80,95 \%$, dan nilai prediksi negatif $90,91 \%$. Sensitivitas CT scan tulang temporal preoperatif dalam menilai erosi pada kolesteatoma tertinggi pada erosi skutum dan tegmen timpani (100\%) dengan spesifisitas dan akurasi CT scan tulang temporal preoperatif dalam menilai erosi pada kolesteatoma tertinggi pada erosi tegmen mastoid (100\% dan 96.29\%). Simpulan penelitian ini ialah CT scan tulang temporal preoperatif memiliki nilai akurasi, sensitivitas, serta spesifisitas yang cukup tinggi dalam menilai kolesteatoma serta erosi pada struktur di sekitarnya.
\end{abstract}

Kata kunci: kolesteatoma, otitis media supuratif kronis (OMSK), CT scan tulang temporal 


\section{PENDAHULUAN}

Otitis media supuratif kronis (OMSK) adalah radang kronis telinga tengah yang ditandai dengan adanya perforasi membran timpani dan riwayat keluarnya sekret dari telinga (otorea), baik terus menerus maupun hilang timbul. ${ }^{1-3}$ Prevalensi yang dilaporkan di negara-negara Asia Tenggara, Afrika, dan Pasifik Barat adalah 2-4\%, sedangkan di Amerika Utara dan negara-negara Eropa $<2 \%{ }^{4}$ Di Indonesia, menurut survei yang dilakukan pada tujuh provinsi pada tahun 1996 ditemukan prevalensi OMSK sebesar $3 \%$ dari penduduk Indonesia. ${ }^{5}$

OMSK dibagi menjadi dua tipe klinis utama: OMSK tanpa kolesteatoma yang secara klinis disebut sebagai tipe aman, dan OMSK dengan kolesteatoma atau tipe bahaya. Kolesteatoma merupakan lesi kistik yang terbentuk dari pertumbuhan keratinisasi epitel skuamosa dan stroma yang dikelilingi dengan reaksi inflamasi di sekitarnya. ${ }^{6}$ Dalam beberapa kasus, kolesteatoma dapat mengakibatkan gangguan pendengaran sensorineural, pusing, cedera nervus fasialis dan komplikasi supuratif seperti mastoiditis akut, abses subperiosteal, trombosis sinus sigmoid, meningitis dan abses otak. ${ }^{2,7}$ Diagnosis dari kolesteatoma biasanya merupakan kombinasi dari temuan klinis termasuk riwayat, pemeriksaan otoskopik/endoskopik dan atau mikrokopik. Pemeriksaan pencitraan tulang temporal dapat memberikan panduan konfirmasi pada kasus-kasus gambaran atipikal (tidak khas) dari kolesteatoma, melihat perluasan penyakit serta diagnosis esensial pertumbuhan kolesteatoma dibalik membran timpani yang tertutup ${ }^{3,8,9}$

Pemeriksaan radiologis pada penyakit telinga tengah cukup menantang dan memerlukan pengetahuan yang dalam mengenai anatomi. CT scan tulang temporal sangat akurat untuk menunjukkan adanya jaringan abnormal di telinga tengah, dengan sensitivitas berkisar antara $70 \%$ hingga $96 \%$, tetapi salah satu keterbatasannya ialah tidak dapat menentukan apakah jaringan tersebut inflamasi, fibrotik atau kolesteatoma. ${ }^{10,11}$ Kolestatoma pada CT scan akan terlihat sebagai soft tissue mass pada telinga tengah yang disertai erosi atau destruksi tulang baik osikula, skutum, kanalis semisirkularis lateral ataupun tegmen timpani. Tanpa erosi atau kerusakan tulang, sulit untuk membedakan kolesteatoma dari jaringan granulasi atau cairan yang terkait dengan otitis media kronis. ${ }^{11-13}$

Berbagai penelitian telah dilakukan di beberapa negara untuk melihat efektifitas CT scan tulang temporal dalam mengevaluasi pasien-pasien dengan kasus OMSK terutama dengan kolesteatoma. Berdasarkan hasil-hasil penelitian tersebut serta penelitian mengenai hubungan dan peran CT scan tulang temporal dengan temuan hasil operasi OSMK dikatakan bahwa CT scan preoperatif memiliki keakuratan diagnosis yang tinggi serta dapat menilai perluasan penyakit sehingga bermanfaat untuk perencanaan pendekatan tindakan bedah yang aman serta bermanfaat dalam melakukan konseling pada pasien sebelum operasi. $9,11,13,14$

\section{METODE PENELITIAN}

Penelitian ini merupakan suatu uji diagnostik yang dilakukan dengan membandingkan temuan pada CT scan tulang temporal preoperatif dengan hasil temuan intraoperatif pada penderita OMSK yang menjalani pemeriksaan $\mathrm{CT}$ scan tulang temporal yang dilanjutkan dengan tindakan operasi di Rumah Sakit Universitas Hasanuddin dan Rumah Sakit Akademis Jaury selama periode Januari 2018 hingga September 2020.

Pemilihan sampel dilakukan dengan consecutive sampling. Kriteria eksklusi ialah pasien OMSK yang disertai dengan tumor pada daerah temporal, riwayat trauma tulang temporal, atau memiliki riwayat pembedahan tulang temporal sebelumnya.

CT scan tulang temporal preoperatif irisan aksial dilakukan tanpa penggunaan kontras dengan ketebalan irisan 0,6 mm yang kemudian direkonstruksi menjadi potongan koronal dan sagittal. Pada evaluasi CT Scan tulang temporal, dianggap sebagai indikasi kolesteatoma bila ditemukan densitas jaringan lunak di telinga tengah yang disertai dengan erosi tulang. Penilaian 
adanya erosi osikula, skutum, tegmen timpani, kanalis nervus fasialis dan tegmen mastoid juga dilakukan (Gambar 1 dan 2). Hasil temuan CT scan tersebut kemudian dibandingkan dengan hasil temuan intraoperasi yang ada di laporan operasi yang telah dilakukan oleh dokter spesialis THT untuk mengetahui nilai sensitivitas, spesifisitas, nilai prediksi positif, serta nilai prediksi negatif dan akurasi.

\section{HASIL PENELITIAN}

Hasil penelitian mendapatkan 54 sampel sejak bulan Januari 2018 sampai dengan bulan September 2020 yang memenuhi kriteria penelitian. Tabel 1 memperlihatkan karakteristik usia sampel, dengan jumlah sampel terbanyak pada kelompok usia remaja (12-25 tahun) sebanyak 46,3\% diikuti kelompok usia dewasa (26-45 tahun) sebanyak $40,7 \%$ dengan rerata usia sampel penelitian 28,13 tahun. Usia sampel yang paling muda 8 tahun sedangkan paling tua 71 tahun. Secara demografis, jumlah sampel dengan jenis kelamin perempuan tampak lebih banyak daripada jumlah laki-laki yaitu sebanyak $29(53,7 \%)$ vs 25 (46,3\%). Berdasarkan CT scan tulang temporal dan temuan operasi, telinga kanan 29 (53,7\%) lebih dominan terkena otitis media supuratif kronik dibandingkan telinga kiri 25 (46,3\%).

Tabel 2 memperlihatkan pada temuan intraoperatif, kolesteatoma didapatkan pada 20 dari 54 sampel. Terdapat 17 sampel penderita kolestetaoma yang berhasil dinilai dari CT scan tulang temporal, namun, terdapat empat sampel yang dinilai sebagai kolestetaoma dari CT scan tulang temporal tetapi tidak didapatkan pada temuan intraoperatif.

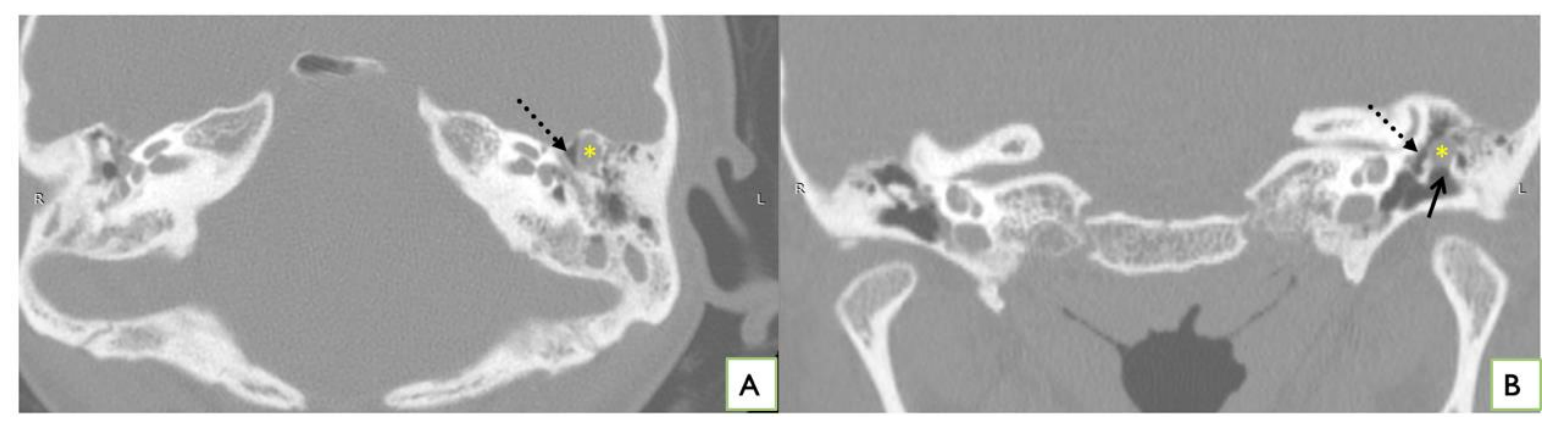

Gambar 1. CT scan tulang temporal irisan aksial (A) dan koronal (B) yang menujukkan soft tissue density pada area epitimpani telinga kiri (*) yang menyebabkan erosi pada skutum (panah hitam) serta pendesakan ke medial dan erosi osikula, yakni head maleus dan body inkus (panah putus-putus) yang dikonfirmasi sebagai kolesteatoma pada temuan intraoperasi

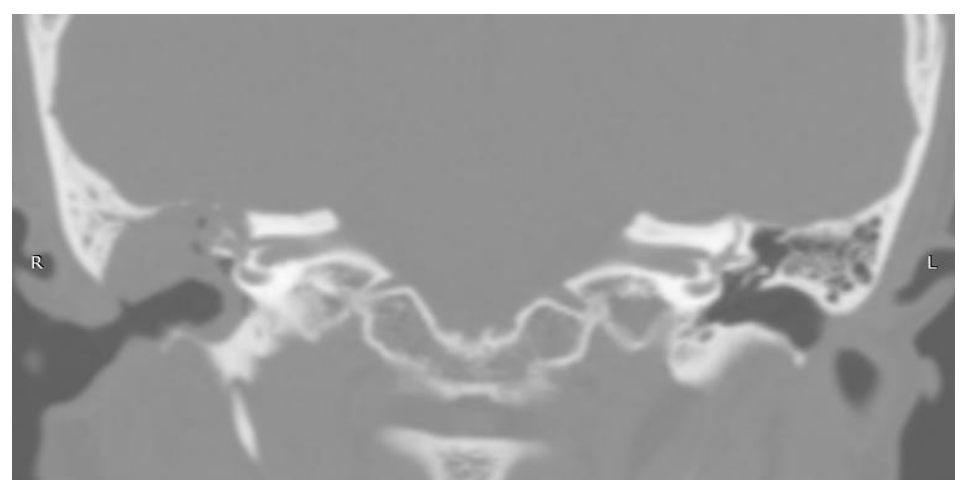

Gambar 2. Potongan koronal menunjukkan kolesteatoma ekstensif $(*)$ yang meluas hingga ke kavum mastoid kanan, mengakibatkan erosi dari skutum serta destruksi osikula, dan erosi dari kanalis fasialis, tegmen timpani serta mastoid. Tampak pula erosi pada kanalis semisirkularis lateral. 
Tabel 1. Sebaran karakteristik sampel penelitian

\begin{tabular}{lcc}
\hline \multicolumn{1}{c}{ Variabel } & $\begin{array}{c}\text { Jumlah } \\
(\mathbf{n})\end{array}$ & $\begin{array}{c}\text { Persentase } \\
(\%)\end{array}$ \\
\hline Usia (tahun) & & \\
Anak (6-11) & 3 & 5,6 \\
Remaja (12-25) & 25 & 46,3 \\
Dewasa (26-45) & 22 & 40,7 \\
Lansia (46-65) & 3 & 5,6 \\
$\quad$ Manula (>65) & 1 & 1,9 \\
Jenis kelamin & & \\
Laki-laki & 25 & 46,3 \\
Perempuan & 29 & 53,7 \\
Lokasi lesi & & \\
$\quad$ Telinga kanan & 29 & 53,7 \\
Telinga kiri & 25 & 46,3 \\
\hline
\end{tabular}

Berdasarkan data tersebut, akurasi CT scan tulang temporal dalam menilai kolesteatoma ialah $87,04 \%$ dengan sensitivitas $85 \%$, spesifisitas $88,23 \%$, nilai prediksi positif $80,95 \%$, dan nilai prediksi negatif $90,91 \%$.

Tabel 3 memperlihatkan dari hasil CT scan temporal terdapat 14 kasus erosi osikula yang berhasil ditemukan intra-operatif, namun terdapat tujuh kasus yang ditemukan intraoperatif tetapi tidak dicurigai pada CT scan sehingga didapatkan sensitivitas CT scan tulang temporal $66,67 \%$, spesifisitas $87,88 \%$, nilai prediksi positif $77,78 \%$, nilai prediksi negatif $80,56 \%$, dan memiliki akurasi $79,62 \%$ dalam menilai erosi osikula.
Tabel 4 memperlihatkan pada temuan intraoperatif, 15 dari 21 yang dicurigai sebagai erosi skutum pada CT scan tulang temporal dapat dibuktikan, dengan tidak ditemukannya negatif palsu. Berdasarkan data tersebut, didapatkan sensitivitas CT scan tulang temporal $100 \%$, spesifisitas $84,61 \%$, nilai prediksi positif $71,42 \%$, nilai prediksi negatif $100 \%$, dan memiliki akurasi $88,89 \%$ dalam menilai erosi skutum.

Tabel 5 memperlihatkan bahwa tidak terdapat kasus negatif palsu, namun terdapat 11 kasus yang dicurigai sebagai erosi tegmen tetapi tidak ditemukan pada intraoperatif. Berdasarkan data tersebut didapatkan sensitivitas $\mathrm{CT}$ scan tulang temporal $100 \%$, dengan spesifisitas $77,55 \%$, nilai prediksi positif $31,25 \%$, nilai prediksi negatif $100 \%$, dan memiliki akurasi 79,62\% dalam menilai erosi tegmen timpani.

Tabel 6 memperlihatkan dua dari tujuh kasus erosi kanalis nervus fasialis yang tidak dicurigai pada CT scan tulang temporal, dengan adanya tiga kasus positif palsu. Berdasarkan data tersebut, CT scan tulang temporal memiliki sensitivitas $66,67 \%$, spesifisitas $93,75 \%$, nilai prediksi positif $57,14 \%$, nilai prediksi negatif $95,74 \%$, dan akurasi $90,74 \%$ dalam menilai erosi kanalis nervus fasialis.

Tabel 2. Tabulasi silang distribusi kasus kolesteatoma berdasarkan CT scan tulang temporal dan temuan intraoperatif

\begin{tabular}{llcccccc}
\hline Kolesteatoma & \multicolumn{4}{c}{ Temuan Operasi } & Total & $\%$ \\
& & \multicolumn{2}{c}{ Ada } & \multicolumn{2}{c}{ Tidak ada } & & \\
& & $\mathrm{n}$ & $\%$ & $\mathrm{n}$ & $\%$ & & \\
\hline Temuan & Ada & 17 & 31,5 & 4 & 7,4 & 21 & 38,9 \\
CT scan & Tidak Ada & 3 & 5,6 & 30 & 55,6 & 33 & 61,1 \\
& Total & 20 & 37,0 & 34 & 63,0 & 54 & 100 \\
\hline
\end{tabular}

Tabel 3. Tabulasi silang erosi osikula berdasarkan CT scan tulang temporal dan temuan intraoperatif

\begin{tabular}{llcccccc}
\hline \multicolumn{1}{c}{ Erosi osikula } & \multicolumn{4}{c}{ Temuan operasi } & Total & \% \\
& & \multicolumn{2}{c}{ Ada } & \multicolumn{2}{c}{ Tidak ada } & & \\
& & $\mathrm{n}$ & $\%$ & $\mathrm{n}$ & $\%$ & & \\
\hline Temuan & Ada & 14 & 25,9 & 4 & 7,4 & 18 & 33,3 \\
CT Scan & Tidak ada & 7 & 13,0 & 29 & 53,7 & 36 & 66,7 \\
& Total & 21 & 38,9 & 33 & 61,1 & 54 & 100 \\
\hline
\end{tabular}


Tabel 4. Tabulasi silang erosi skutum berdasarkan CT scan tulang temporal dan temuan intraoperatif

\begin{tabular}{llcccccc}
\hline \multirow{2}{*}{ Erosi skutum } & \multicolumn{4}{c}{ Temuan operasi } & Total & \% \\
& & \multicolumn{2}{c}{ Ada } & \multicolumn{2}{c}{ Tidak ada } & & \\
& & $\mathrm{n}$ & $\%$ & $\mathrm{n}$ & $\%$ & & \\
\hline Temuan & Ada & 15 & 27,8 & 6 & 11,1 & 21 & 38,9 \\
CT Scan & Tidak ada & 0 & 0 & 33 & 61,1 & 33 & 61,1 \\
& Total & 15 & 27,8 & 39 & 72,2 & 54 & 100 \\
\hline
\end{tabular}

Tabel 5. Tabulasi silang erosi tegmen timpani berdasarkan CT scan tulang temporal dan temuan intraoperatif

\begin{tabular}{|c|c|c|c|c|c|c|c|}
\hline \multirow{2}{*}{\multicolumn{2}{|c|}{ Erosi tegmen timpani }} & \multicolumn{4}{|c|}{ Temuan operasi } & \multirow{3}{*}{ Total } & \multirow{3}{*}{$\%$} \\
\hline & & \multicolumn{2}{|c|}{ Ada } & \multicolumn{2}{|c|}{ Tidak ada } & & \\
\hline & & $\mathrm{n}$ & $\%$ & $\mathrm{n}$ & $\%$ & & \\
\hline \multirow{3}{*}{$\begin{array}{l}\text { Temuan } \\
\text { CT Scan }\end{array}$} & Ada & 5 & 9,3 & 11 & 20,3 & 16 & 29,6 \\
\hline & Tidak ada & 0 & 0 & 38 & 70,4 & 38 & 70,4 \\
\hline & Total & 5 & 9,3 & 49 & 90,7 & 54 & 100 \\
\hline
\end{tabular}

Tabel 6. Tabulasi silang erosi kanalis nervus fasialis berdasarkan CT scan tulang temporal dan temuan intraoperatif

\begin{tabular}{llcccccc}
\hline & & \multicolumn{9}{c}{ Temuan operasi } & & \\
\multirow{2}{*}{ Erosi kanalis n.fasialis } & \multicolumn{2}{c}{ Ada } & \multicolumn{2}{c}{ Tidak ada } & Total & $\%$ \\
& & $\mathrm{n}$ & $\%$ & $\mathrm{n}$ & $\%$ & & \\
\hline Temuan & Ada & 4 & 7,4 & 3 & 5,6 & 7 & 13,0 \\
CT Scan & Tidak ada & 2 & 3,7 & 45 & 83,3 & 47 & 87,0 \\
& Total & 6 & 11,1 & 48 & 88,9 & 54 & 100 \\
\hline
\end{tabular}

Tabel 7. Tabulasi silang erosi tegmen mastoid berdasarkan CT scan tulang temporal dan temuan intraoperatif

\begin{tabular}{llcccccc}
\hline \multirow{2}{*}{ Erosi tegmen mastoid } & \multicolumn{4}{c}{ Temuan operasi } & Total & $\%$ \\
& & Ada & \multicolumn{2}{c}{ Tidak ada } & & \\
& & $\mathrm{n}$ & $\%$ & $\mathrm{n}$ & $\%$ & & \\
\hline Temuan & Ada & 6 & 11,1 & 0 & 0 & 6 & 11,1 \\
CT Scan & Tidak Ada & 2 & 3,7 & 46 & 85,2 & 48 & 88,9 \\
& Total & 8 & 14,8 & 46 & 85,2 & 54 & 100 \\
\hline
\end{tabular}

Tabel 7 memperlihatkan bahwa tidak terdapat kasus positif palsu pada erosi tegmen mastoid, namun terdapat dua kasus yang ditemukan intraoperatif tetapi tidak dicurigai pada CT scan. Berdasarkan data tersebut, sensitivitas CT scan tulang temporal $75 \%$, spesifisitas $100 \%$, nilai prediksi positif $100 \%$, nilai prediksi negatif 95,83\%, dan memiliki akurasi 96,29\% dalam menilai erosi tegmen mastoid.

\section{BAHASAN}

Pada penelitian ini, dilakukan penilaian ada atau tidaknya kolesteatoma dengan ditemukannya densitas jaringan lunak pada telinga tengah yang disertai dengan erosi tulang disekitarnya, seperti erosi osikula ataupun erosi skutum. Selain itu dilakukan 
pula penilaian perluasan dari kolesteatoma dengan melihat adanya erosi tegmen timpani, erosi pada kanalis nervus fasialis, serta erosi pada tegmen mastoid.

Berdasarkan karakteristik usia sampel, jumlah sampel penelitian terbanyak pada kelompok usia remaja (12-25 tahun) sebanyak 46,3\% diikuti kelompok usia dewasa (26-45 tahun) sebanyak 40,7\%. Usia sampel penelitian yang paling muda 8 tahun sedangkan paling tua 71 tahun. Dalam studi yang dilakukan oleh Chavada et $\mathrm{al}^{15}$ kelompok usia yang paling umum ialah 1120 tahun sebanyak $25 \%$, diikuti oleh $21-30$ tahun sebanyak memiliki $23 \%$ dan $17 \%$ pada kelompok usia 0-10 tahun. Usia rerata sampel ialah 24,5 tahun sedangkan dalam penelitian ini 28,11 tahun. Hal ini dihubungkan dengan kejadian OMSK yang hampir selalu dimulai dengan otitis media berulang pada anak. Alasan terjadinya hal ini ialah letak dan ukuran tuba Eustachius yang lebih pendek dan datar sehingga mudah mendapatkan infeksi telinga tengah. Selain itu, fungsi imunologik anak yang masih rendah ikut mempunyai andil dalam munculnya otitis media berulang. ${ }^{5}$

Secara demografis, sebaran sampel lebih banyak didapatkan pada jenis kelamin perempuan yaitu sebanyak 29 sampel $(53,7 \%)$ dibandingkan laki-laki sebanyak 25 sampel $(46,3 \%)$. Hal ini sesuai dengan penelitian yang dilakukan Prata et al ${ }^{14}$ yang mendapatkan pasien perempuan sebesar 53,8\% dan laki-laki 46,2\%. Demikian pula penelitian yang dilakukan oleh Chavada et $\mathrm{al}^{15}$ yang melaporkan dari 100 sampel, terdapat $58 \%$ berjenis kelamin perempuan dan $42 \%$ berjenis kelamin laki-laki.

Pada penelitian ini, telinga yang lebih banyak mengalami OMSK dan mendapatkan penanganan berupa operasi yakni telinga kanan dibandingkan telinga kiri. Hasil penelitian ini selaras dengan penelitian oleh Prata et $\mathrm{al}^{14}$ yang mendapatkan dari 82 sampel, 42,3\% kelainan pada telinga kanan, 32,5\% pada telinga kiri, dan 20\% pada kedua telinga. Hasil yang berbeda dilaporkan oleh Chavada et al ${ }^{15}$ yaitu telinga kiri lebih banyak dibandingkan telinga kanan. Perbedaan data ini dimungkinkan karena perbedaan jumlah sampel yang diambil untuk diteliti.

CT scan tulang temporal sangat baik dalam menunjukkan adanya jaringan lunak pada telinga tengah dan mastoid, namun pemeriksaan ini tidak dapat menentukan apakah jaringan tersebut berupa jaringan inflamasi, fibrotik, atau kolesteatoma. Adanya erosi tulang pada beberapa struktur seperti osikula, tegmen timpani, scutum, dan kanalis semisirkularis, sangat mengindikasikan kolesteatoma pada suatu otitis media kronis. ${ }^{10,11}$

Pada penelitian ini, peniliaian kolesteatoma melalui CT scan tulang temporal preoperatif pada total 54 sampel berdasarkan adanya densitas jaringan lunak telinga tengah disertai erosi tulang. Berdasarkan kriteria tersebut, 17 dari 20 sampel penderita kolesteatoma yang berhasil dinilai dari CT scan tulang temporal. Terdapat empat sampel yang dinilai sebagai kolestetaoma dari CT scan tulang temporal namun tidak didapatkan pada temuan intraoperatif sehingga didapatkan akurasi CT scan tulang temporal dalam menilai kolesteatoma ialah $87,04 \%$ dengan sensitivitas $85 \%$, spesifisitas $88,23 \%$, nilai prediksi positif $80,95 \%$, dan nilai prediksi negatif 90,91\% (Tabel 2).

Di negara-negara lain, terdapat beberapa penelitian terdahulu yang menilai akurasi CT scan preoperatif dalam menilai kolesteatoma dibandingkan dengan temuan intraoperatif. Penelitian Kucur et $\mathrm{al}^{16}$ di Turki dengan 50 sampel, mendapatkan sensitivitas $60 \%$ dan spesifisitas $77,7 \%$ sedangkan Prata et $\mathrm{al}^{14}$ di Brazil mendapatkan sensitivitas $72,73 \%$ dan spesifisitas $82,5 \%$ dengan jumlah sampel 62 pasien. Selain itu, Chavada et al ${ }^{15}$ di India mendapatkan sensitivitas $98,7 \%$, sensitivitas $72,91 \%$, serta akurasi $93 \%$ dari 100 sampel. Perbedaan ini mungkin didapatkan karena adanya perbedaan spesifikasi detektor dari alat CT scan serta ketebalan irisan. Pada penelitian yang dilakukan oleh Kucur et $\mathrm{al}^{16}$ dan Prata et $\mathrm{al}^{14}$ digunakan irisan dengan ketebalan $1 \mathrm{~mm}$ sedangkan pada penelitian ini digunakan irisan dengan ketebalan 0,6 mm.

Pada penelitian ini, penilaian koles- 
teatoma pada CT scan ditegakkan dengan adanya densitas jaringan lunak telinga tengah disertai erosi tulang sehingga pada kolestatoma yang belum disertai dengan erosi sulit dibedakan dengan jaringan lain yang bukan kolesteatoma oleh karena densitasnya sama. Selain itu, dari temuan operasi, erosi tulang berupa erosi osikula tidak hanya terdapat pada kolesteatoma, namun juga dapat terjadi pada kasus otitis media adhesif, granuloma, serta hipertrofi mukosa. Hal ini yang menyebabkan didapatkannya kejadian positif palsu dalam penilaian kolestetaoma pada gambaran CT scan tulang temporal sebagaimana pada penelitian ini. Berdasarkan teori, otisis media adhesif memang memiliki komplikasi berupa erosi osikula karena adanya retraksi membran timpani ke osikula yang menyebabkan pasokan darah menurun ke osikula. ${ }^{17}$ Penelitian yang dilakukan Haidar et $\mathrm{al}^{18}$ di Qatar melaporkan dari 66 kasus erosi osikula, sekitar $13,9 \%$ terjadi pada OMSK tipe aman. Hal ini dikaitkan dengan pembentukan mediator inflamasi yang berlebihan di dalam kavum timpani yang menginduksi aktivasi osteoklas dan resorpsi tulang yang berakibat destruksi osikula. Lamanya proses inflamasi merupakan faktor yang tampaknya paling berpengaruh terhadap osikula. ${ }^{18}$

Penilaian struktur anatomi telinga tengah dan tulang temporal dengan menggunakan CT scan memerlukan irisan bidang yang berbeda, yakni irisan aksial dan koronal. Struktur seperti skutum, tegmen timpani, kepala maleus, prosesus longus inkus, dan segmen horizontal dari kanalis nervus fasialis lebih sesuai dievaluasi pada irisan koronal sedangkan sinus timpani, segmen vertikal dari kanalis nervus fasialis dan stapes lebih sesuai dievaluasi pada irisan aksial. ${ }^{16}$

CT scan tulang temporal mampu mencurigai 14 dari 21 kasus erosi osikula, serta terdapat empat kasus yang diperkirakan namun tidak ditemukan erosi dalam operasi sehingga didapatkan sensitivitas $66,67 \%$, spesifisitas $87,88 \%$, nilai prediksi positif $77,78 \%$, nilai prediksi negatif $80,56 \%$, dan akurasi 79,62\% (Tabel 3). Hasil ini sejalan dengan yang didapatkan Prata et $\mathrm{al}^{14}$ yaitu sensitivitas $56,67 \%$, spesifisitas $84,37 \%$, nilai prediksi positif $77,27 \%$, dan nilai prediksi negati $67,5 \%$. Beberapa literatur melaporkan hasil yang cukup bervariasi dengan perkiraan antara 50-100\%. Hal ini dikaitkan dengan osikula yang mengalami erosi. Pada beberapa penelitian, korelasi erosi osikula antaran CT scan dengan temuan bedah lebih tinggi pada maleus serta korpus dan prosesus brevis inkus jika dibandingkan dengan stapes dan prosesus longus inkus. ${ }^{12,14,15}$

Pada penelitian ini, CT scan preoperatif baik dalam menilai erosi skutum dimana didapatkan 6 positif palsu dan tidak adanya negatif palsu sehingga sensitivitas CT scan tulang temporal $100 \%$, spesifisitas $84,61 \%$, nilai prediksi positif $71,42 \%$, nilai prediksi negatif $100 \%$, dan akurasi $88,89 \%$ (Tabel 4). Penilaian skutum pada penelitian ini dengan melihat terkikisnya struktur outer attic wall yang harusnya tajam, dan juga dibandingkan dengan skutum kontralateral sehingga penilaian pada irisan yang tidak simetris dapat menyebabkan interpretasi yang berbeda dari kondisi yang sebenarnya atau positif palsu.

Komplikasi kolesteatoma terjadi ketika lesi mengikis batas anatomis telinga tengah, antrum, dan mastoid, atau melibatkan nervus fasialis. Komplikasi yang paling umum ialah erosi kanalis fasialis, tegmen timpani, tegmen mastoid, serta fistula kanalis semisirkularis. Setiap informasi yang diberikan oleh CT scan dapat bermanfaat dalam mencegah kemungkinan kerusakan pada struktur-struktur ini dan mengurangi risiko komplikasi lanjut. Dalam penelitian ini, seluruh erosi tegmen timpani dapat dideteksi, namun tedapat 11 hasil positif palsu, sehingga didapatkan sensitivitas CT scan tulang temporal $100 \%$, spesifisitas $77,55 \%$, nilai prediksi positif $31,25 \%$, nilai prediksi negatif $100 \%$, dan akurasi 79,62\% (Tabel 5). Hasil ini lebih baik dibandingkan dengan penelitian yang dilaporkan oleh Prata et al ${ }^{14}$ dan Chavada et al. ${ }^{15}$

Dalam menilai erosi kanalis fasialis, pada penelitian ini CT scan dapat memperkirakan empat dari enam kasus dengan 
didapatkan adanya tiga positif palsu, sensitivitas CT scan tulang temporal $66,67 \%$, spesifisitas $93,75 \%$, nilai prediksi positif $57,14 \%$, nilai prediksi negatif 95,74\%, dan memiliki akurasi 90,74\% (Tabel 6). Kurangnya sensitivitas CT scan dalam menilai erosi kanalis nervus fasialis dan juga tegmen timpani dikarenakan tipisnya tulang yang membentuk kanalis nervus fasialis dan tegmen timpani sehingga sulit dinilai terutama dengan adanya jarringan lunak disekitarnya. ${ }^{14,19}$ Selain itu, hal ini juga mungkin dapat dipengaruhi oleh perbedaan jumlah detektor pada alat yang digunakan dalam penelitian ini yaitu penelitian dilakukan di dua rumah sakit yang memiliki spesifikasi alat CT scan berbeda yang mungkin dapat memengaruhi kualitas gambar walaupun keduanya menggunakan ketebalan irisan yang sama.

Dalam menilai erosi tegmen mastoid, dapat diperkirakan enam dari delapan kasus dengan tidak didapatkan positif palsu, sehingga sensitivitas $\mathrm{CT}$ scan tulang temporal $75 \%$, spesifisitas $100 \%$, nilai prediksi positif $100 \%$, nilai prediksi negatif $95,83 \%$, dan memiliki akurasi 96,29\% (Tabel 7). Erosi pada tegmen mastoid terjadi pada kolesteatoma yang ekstensif sehingga pada CT scan dapat terlihat dengan cukup jelas.

\section{SIMPULAN}

CT scan tulang temporal preoperatif memiliki nilai akurasi, sensitivitas, serta spesifisitas yang cukup tinggi dalam menilai kolesteatoma serta erosi pada struktur di sekitarnya sehingga pemeriksaan CT scan tulang temporal pada penderita OMSK dapat dijadikan sebagai salah satu panduan dalam kepentingan klinik baik untuk penilaian kolesteatoma dan perluasannya maupun sebagai panduan tentang strukturstruktur yang perlu diberi perhatian dalam tindakan operatif nantinya.

\section{Konflik Kepentingan}

Penulis menyatakan tidak terdapat konflik kepentingan dalam studi ini.

\section{DAFTAR PUSTAKA}

1. Mittal R, Lisi CV, Gerring R, Mittal J, Mathee
K, Narasimhan G, et al. Current concepts in the pathogenesis and treatment of chronic suppurative otitis media. J Med Microbiol. 2015;64(10): 1103-16. Doi:10.1099/jmm.0.000155.

2. Yorgancilar E, Yildirim M, Gun R, Bakir S, Gocmez C, Meric F, et al. Compli cations of chronic suppurative otitis media: a retrospective review. Eur Arch Otorhinolaryngol. 2013;270(1):69-76. Doi:10.1007/s00405-012-1924-8.

3. Helmi. Otitis media supuratif kronis. Jakarta: Balai Penerbit FKUI, 2005; p. 29-41.

4. Park M, Lee JS, Lee JH, Oh SH, Park MK. Prevalence and risk factors of chronic otitis media: the Korean National Health and Nutrition Examination Survey 2010-2012. PLoS One. 2015;10(5): e0125905. Doi:10.1371/journal.pone. 0125905.

5. Asroel H, Siregar D, Aboet A. Profil penderita otitis media supuratif kronis. Kesmas: Jurnal Kesehatan Masyarakat Nasional (National Public Health Journal), 2013; 7(12):567-71. Doi:http://dx.doi.org/10. 21109/kesmas.v7i12.332.

6. Semaan MT, Megerian CA. The pathophysiology of cholesteatoma. Otolaryngol Clin North Am. 2006;39(6):1143-59.

Doi:10.1016/j.otc.2006.08.003.

7. Sari JTY, Edward Y, Rosalinda S. Otitis media supuratif kronis tipe kolesteatom dengan komplikasi meningitis dan paresis nervus fasialis perifer. Jurnal Kesehatan Andalas. 2018;7(Suppl4):88-95. Doi: https://doi.org/10.25077/jka.v7i0.931.

8. Gyanu J, Modwal A, Saboo R, Saxena G, Sapra G. A study of the correlation of the clinical feature, radiological evaluation and operative finding in CSOM with cholesteatoma. Sch J App Med Sci. 2014;2(6F):3259-69. Doi: https://doi. org/10.25077/jka.v7i0.931.

9. Ayache D, Darrouzet V, Dubrulle F, Vincent C, Bobin S, Williams M, et al. Imaging of non-operated cholesteatoma: Clinical practice guidelines. Eur Ann Otorhinolaryngol Head Neck Dis. 2012;129(3): 148-52. Doi: 10.1016/j.anorl.2011. 09.005.

10. De Ávila AFA, Aburjeli BOM, Moreira W, Motta EGPC. Imaging evaluation of middle ear cholesteatoma: iconographic essay. Radiol Bras. 2013;46(4):247-51. Doi: http://dx.doi.org/10.1590/S0100- 
39842013000400012.

11. Jose J, George UB, Varghese A, Rathore S. Correlation between high-resolution computed tomography temporal bone findings and surgical findings in patients with inflammatory diseases of the middle ear. CHRISMED J Health Res 2019;6(3):140-5. Doi: 10.4103/cjhr. cjhr_161_18.

12. Gulati M, Gupta S, Prakash A, Garg A, Dixit R. HRCT imaging of acquired cholesteatoma: a pictorial review. Insight into Imaging. 2019;10:92. Doi: 10.1186/s13244-019-0782-y.

13. Gomaa MA, Abdel Karim ARA, Abdel Ghany HS, Elhiny AA, Sadek AA. Evaluation of temporal bone cholesteatoma and the correlation between high resolution computed tomography and surgical finding. Clin Med Insights Ear Nose Throat. 2013;6:21-8. Doi:10.4137/ CMENT.S10681.

14. Prata AAS, Antunes ML, Abreu CEC, Frazatto R, Lima BT. Comparative study between radiological and surgical findings of chronic otitis media. Int Arch Otorhinolaryngol. 2011;15(1):72-8. Doi: 10.1590/S1809-487220110001000 11.

15. Chavada PS, Khavdu PJ, Fefar AD, Mehta
MR. Middle ear cholesteatoma: a study of correlation between HRCT temporal bone and intraoperative surgical findings. Int J Otorhinolaryngol Head Neck Surg. 2018;4(5):1252-7. Doi: http://dx.doi.org/10.18203/issn. 2454-5929.ijohns20183702.

16. Kucur C, Simsek E, Kuduban O, Celebi I. The clinical value of temporal bone tomography in chronic otitis media. Kulak Burun Bogaz Ihtis Derg 2013;23(1):2125. Doi: 10.5606/kbbihtisas.2013.30164.

17. Mansour S, Magnan J, Nicolas K, Haidar H. Adhesive otitis media. In: Middle Ear Diseases. Springer, Cham, 2018. Doi: https://doi.org/10.1007/978-3-31972962-6_4.

18. Haidar H, Sheikh R, Larem A, Elsaadi A, Abdulkarim H, Ashkanani S, et al. Ossicular chain erosion in chronic suppurative otitis media. Otolaryngol (Sunnyvale), 2015;5(4):203. Doi: 10.4172/2161-119X.1000203.

19. Banerjee A, Flood LM, Yates P, Clifford K. Computed tomography in suppurative ear disease: does it influence management? J Laryngol Otol. 2003;117(6): 454-8. Doi:10.1258/00222150332189 2280. 